\title{
Determinants of urban mobility in India: Lessons for promoting sustainable and inclusive urban transportation in developing countries
}

\author{
Ahmad, Sohail a, b* Puppim de Oliveira, Jose A. ${ }^{\text {c, d, e, f, g }}$ \\ ${ }^{a}$ Mercator Research Institute on Global Commons and Climate Change (MCC), Torgauer Straße 12-15, \\ D-10829 Berlin, Germany \\ ${ }^{\mathrm{b}}$ Department Economics of Climate Change, Technical University of Berlin, Strasse des 17. Juni 145, D- \\ 10623 Berlin, Germany \\ ${ }^{c}$ Fundação Getulio Vargas (FGV), São Paulo School of Business Administration (FGV/EAESP), and \\ Brazilian School of Public and Business Administration (FGV/EBAPE), Brazil \\ ${ }^{\mathrm{d}}$ COPPEAD Institute, Federal University of Rio de Janeiro (COPPEAD/UFRJ), Brazil \\ e School of International Relations and Public Affairs (SIRPA), Fudan University, China \\ ${ }_{\mathrm{f}}^{\mathrm{f}}$ United Nations University International Institute for Global Health (UNU-IIGH), Kuala Lumpur, \\ Malaysia \\ g MIT-UTM Malaysia Sustainable Cities Program (2015-2016), Johor Bahru, Malaysia and Cambridge, \\ MA, USA \\ E-mails: (Ahmad, S.) architectsohail@gmail.com, ahmad@mcc-berlin.net; (Pippim de Oliveira, J.A.) \\ japo3@yahoo.com
}

* Corresponding Author (Present Address and Contact):

Mercator Research Institute on Global Commons and Climate Change (MCC)

Torgauer Straße 12-15

10829 Berlin, Germany 
Graphic Abstract

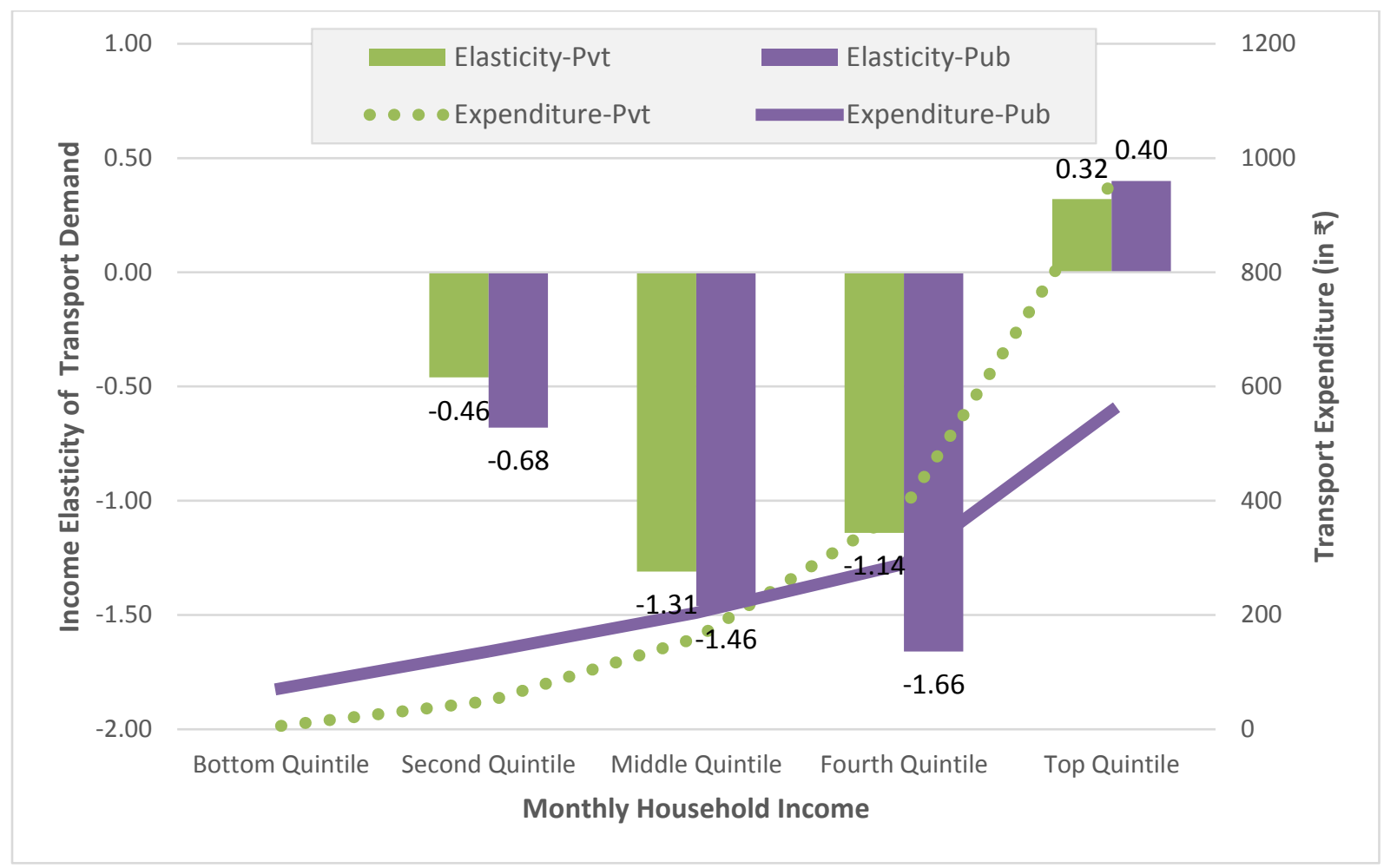


Highlights

- Densification reduces mobility needs and enhances public transport.

- Large cities use public transport more, but lack non-motorized transport.

- The amount of transport increases with city size (by population).

- The household income is the single largest determinant of the amount of transport.

- Indian cities need investments in public and non-motorized transport infrastructures and disincentives of private modes.

\begin{abstract}
Studies from developed economies have analyzed the key factors for understanding urban mobility, which are important to design appropriate interventions to reduce the volume of transport needs and to promote more sustainable modes of transportation. However, there are limited studies in urban areas of developing economies, which can hinder our capacity to formulate sustainable transport policies that are fit for the reality of those countries. In order to fill this gap, this study quantifies the influence of city features and socio-economic and socio-cultural variables on mobility patterns to identify evidencebased policy interventions for promoting more inclusive and sustainable transportation paths. The research estimates the amount of public and private transport (proxied by out-of-pocket travel expenditure) and modal choices, employing multivariate analyses, using a nationally representative household survey from the 98 largest Indian cities. Findings reveal that densification in Indian cities reduces the amount of transport as well as enhances the probability of using public transport. Small and medium-sized cities predominantly use private transport, whereas large cities prefer public transport but lack non-motorized transportation. Moreover, income is the most important determinant of the amount of transport and the use of motorized and private transport. The top quintile is the only with positive income elasticity of transport demand. Results show that public and non-motorized transport infrastructures will provide sustainable and inclusive development, besides other co-benefits, such as energy security. Based on these findings, several policy recommendations are proposed to improve the sustainability and inclusivity of urban mobility in Indian cities.
\end{abstract}

Keywords: Travel behavior; Travel demand; Modal choice; Urban form; India; Multivariate analysis; Sustainable Development Goals; Developing country 


\section{Determinants of urban mobility in India: Lessons for promoting sustainable and inclusive urban transportation in developing countries}

\section{Introduction}

Sustainable urban mobility is a major challenge in rapidly urbanizing medium- and low-income cities causing serious health, economic, social and environmental problems. This can be best addressed through appropriate transportation policies and programs using evidence-based interventions, which require thorough understanding of patterns of urban mobility. Broadly, mobility patterns depend, among other things, upon urban form, socio-economic and socio-cultural attributes of urban dwellers. Unlike well documented studies in developed economies (Creutzig, 2014; P. Gordon \& Richardson, 1989; Makido, Dhakal, \& Yamagata, 2012; Mindali, Raveh, \& Salomon, 2004; P. Naess, 1995; Newman \& Kenworthy, 1989), limited studies assess patterns of mobility in cities of developing economies, including India. These cities cannot rely on the evidence of those in developed economies, given large differences between them, such as infrastructure, economic conditions and administrative capacities. Thus, this study identifies the main determinants of urban mobility in India and draws lessons for promoting effective transportation policies fit for Indian and other cities in developing countries.

On the one hand, cities in developing countries are facing an acute urban transport crisis (Pucher, Korattyswaropam, Mittal, \& Ittyerah, 2005; Sudhakara Reddy \& Balachandra, 2012). On the other hand, these cities are expected to contribute up to $89 \%$ of the increase in $\mathrm{CO}_{2}$ emissions from urban areas until 2030 (IEA, 2008), in large part from the urban transport sector. Transport is responsible for about $23 \%$ of total energy-related $\mathrm{CO}_{2}$ emissions worldwide and projected to double by 2050 (Sims et al., 2014). However, emissions from the transport sector could be reduced to half by mid-century if policy-makers use the full suite of policies at their disposal (Creutzig et al., 2015). Carbon dioxide emissions per capita is more strongly correlated to urbanization than to per capita income (Sethi \& Puppim de Oliveira, 2015). One of the Sustainable Development Goals (SDGs) adopted by the United Nations is to "Make cities and human settlements inclusive, safe, resilient and sustainable" (Goal 11). This goal sets as one of its targets that "by 2030, provide access to safe, affordable, accessible and sustainable transport systems for all, improving road safety, notably by expanding public transport, with special attention to the needs of those in vulnerable situations, women, children, persons with disabilities and older persons"(United Nations, 2015). There is also a growing trend to decentralize government decisions to local and other sub-national governments, increasing the need to further improve their capacity to properly manage public urban demands (Puppim de Oliveira, Jing, \& Collins, 2015). Moreover, there is a huge potential for innovative interventions in Indian cities that can bring climate co-benefits and facilitate a more sustainable urbanization (Sethi \& Puppim de Oliveira, forthcoming).

In India, the growing urban population further demands transport infrastructures, but cities lack proper roads, public transport and non-motorized transport (NMT) infrastructures. Often the provisions of transport infrastructures are not demand-driven or evidence-based, but ticket projects based on political decisions. As a result, even at lower vehicular ownership compared to developed and other developing economies, Indian cities face severe congestion and air pollution leading to health problems and economic losses. 
The High Powered Expert Committee of the Ministry of Urban Development estimated urban infrastructure investments to the tune of ₹39.2 Billion ${ }^{1}$ (at 2009-10 prices), over the next 20 years (Ministry of Urban Development, 2011). Out of these investments, urban roads need $44 \%$, and transport and traffic need $14 \%$. Recently the central government introduced the Atal Mission for Rejuvenation and Urban Transformation (AMRUT) for 500 cities with an outlay of ₹500 Billion over the next five years (2015 to 2019), which will improve, among others, pedestrian, non-motorized and public transport facilities, and parking spaces. Additionally, the government also approved the Smart Cities Mission with an outlay of ₹480 Billion.

In this context, this study estimates determinants of urban transport (public and private) and modal choice (motorized versus non-motorized, and public versus private), using multivariate regressions, particularly focusing on the city features and socio-economic and socio-cultural variables. Based on a nationally representative household survey from 98 Indian cities, this empirical study reveals that densification reduces mobility needs and enhances the use of public transportation, ceteris paribus. Additionally, the amount of transport increases with city size (by population). Moreover, small- and medium-sized cities predominantly use private transport, whereas large cities use more public transport but lack nonmotorized transport. Based on these empirical findings, among others, we suggest evidence-based interventions to achieve sustainable urban mobility in Indian cities. Thus, this empirical investigation contributes to the urban transport literature in India as well as to the global policy discussions on sustainable urbanization.

The remaining part of this section discusses urbanization and transportation scenarios in India and gives a brief literature review of the factors explaining variation in urban transportation. Section 2 presents methods and data, Section 3 presents empirical results and discussion, and Section 4, the final section, concludes with spatial policy interventions vital for inclusive and sustainable development in Indian cities.

\section{Urbanization and transportation scenario in India}

Despite the lower level of urbanization ${ }^{2}$ (32\%), India has the second largest urban population(377 million) in the world after China (Census of India, 2011b), and India's urban population is growing at a faster pace. In the last decade (2001-11), cities added 91 million inhabitants, approximately $44 \%$ from natural growth, and the remaining $56 \%$ from net rural-urban classification and rural-to-urban migration (Bhagat, 2011). About 50\% of urban population live in urban centres of fewer than $0.5 \mathrm{M}$ inhabitants. The remaining are distributed as following: $7 \%$ in $0.5-1 \mathrm{M} ; 17 \%$ in $1-5 \mathrm{M} ; 9 \%$ in $5-10 \mathrm{M}$; and $17 \%$ in over $10 \mathrm{M}$ inhabitants. An estimate from the United Nations reveals that the population shares will decrease in smallsized cities and increase in large-sized cities (UNDESA, 2014. See also Fig. 1). Cities have large variations in growth rates among themselves, with two distinct features: the growth rate of cities over $1 \mathrm{M}$ is higher than cities with less than $1 \mathrm{M}$ inhabitants; and the growth rate is negatively associated with the size of town or city (Bhagat, 2004). Over the last decade, the number of census towns has increased

\footnotetext{
$1 ₹=$ Indian rupee (US\$ 1 was approximately ₹ 60 in 01/2015, and \$ PPP conversion rate is expected to be 19.38 ₹ per US\$ in 2015)

${ }^{2}$ Urban area is defined as (1) "All places with a municipality, corporation, cantonment board or notified town area committee, etc."; and (2) "all other places which satisfies the following three criteria: (i) A minimum population of 5000; (ii) At least $75 \%$ of the male main working population engaged in non-agricultural pursuits; and (iii) A density of population of at least 400 persons per sq. km" (Census of India, 2011a).
} 
dramatically 2532 (1,362 to 3,894), out of a total increase in 2,774 towns and Urban Agglomerations(UAs) ${ }^{3}$, having core characteristics of urban areas, without appropriate governance mechanism and infrastructures (Census of India, 2011b).

Insert Fig. 1 here: Number of cities and percentage of urban population by urban settlement size in India, $1990-2025$

In Indian cities, a major share of population travels with non-motorized modes (number of trips), such as walking and cycling (about $40 \%$ ), while $15 \%$ uses public transport, $36 \%$ uses private transport (20\% twowheelers and $16 \%$ four-wheelers) and 5\% uses intermediate public transit ${ }^{4}$ (MOUD, 2008). On an average, household spent about ₹279 on public and ₹347 on private conveyance per month (NSSO, 2010b). Estimate reveals shares of private and informal public transport will increase and public transport will decrease in the coming decades (MOUD, 2008). Even large cities have significant variation in transport modes. With city size, shares of public transport increase and non-motorized transport decrease, particularly among cities over $0.5-1 \mathrm{M}$ size. Thus, understanding the influence of city features in urban transport choices in India could shed more light on the best way to promote sustainable transportation and achieving the SDGs.

Insert Fig. 2 here: Mode share (number of trips) by city size, 2007

\section{Factors explaining variation in urban mobility}

Previous studies reveal urban form, socio-economic and socio-cultural variables, among others, explain the variation in urban mobility. Urban form is the spatial pattern of human settlements and activities at a particular point of time. Varieties of urban forms, including physical and non-physical features (Huang, Lu, \& Sellers, 2007; Jenks, 2001; Schneider \& Woodcock, 2008) are observed at different spatial scales (Vaidya \& Ray, 2011). Jabareen (2006), for instance, outlines four types of urban forms - neotraditional development, urban containment, compact city, and eco-city - with a combination of seven design concepts: compactness, sustainable transport, density, mixed land uses, diversity, passive solar design and greening. Sustainable urban form aims to achieve different objectives; the most prominent among them are lesser energy use, reduced waste and pollution, reduced automobile use and congestion, preservation of open space and sensitive ecosystems, and liveable and community-oriented human environments. Even though there are examples of the integration of land-use and transportation models, such as the case of Curitiba in Brazil (Rabinovitch \& Leitmann, 1993), they are often not replicable in other contexts. Thus, academia and practitioners are still in search of convincing general models of sustainable urban form and its components. Nevertheless, scholars and urban planners have attempted to address a few of the objectives through employing particular elements of urban form. For example, Lohrey and Creutzig (2015) identify a sustainable window for the sweet spot of urban form, which modifies sustainability concerns related to greenhouse gas emissions, local air pollution and congestion.

\footnotetext{
${ }^{3}$ An Urban Agglomeration (UA) is "a continuous urban spread constituting a town and its adjoining outgrowths (OGs), or two or more physically contiguous towns together with or without outgrowths of such towns. An UA must consist of at least a statutory town and its total population (i.e. all the constituents put together) should not be less than 20,000 as per the 2001 Census" (Census of India, 2011a).

${ }^{4}$ Auto rickshaw (three wheeler)
} 
Empirical studies from the built environment-travel literature reveals travel demand is generally inelastic with respect to changes in measures of the built environment (Ewing \& Cervero, 2010). Vehicular energy consumption is negatively associated with densification. Newman and Kenworthy (1989), for example, showed the negative correlation between urban density and gasoline consumption using cross sectional data from 32 large cities around the world. Karathodorou, Graham et al. (2010) estimated a fuel demand model for 84 urban areas in different countries and found that the elasticities of car ownership, annual distance driven, and fuel consumption per km with respect to urban density were $-0.12,-0.24$ and -0.35 , respectively. $\mathrm{Su}$ (2011) using U.S. household data, estimated the elasticity of gasoline consumption to population density to be -0.064 , holding household characteristics, freeway road density, and congestion constant. Naess (1995), using the case of Oslo, showed that residents living in high density and near to downtown travel considerably shorter distances and use less energy than those who live in low density and outer areas.

Besides density, association between settlement size and urban mobility (the amount of transport and modal choices) has been well investigated (Stead \& Marshall, 2001). However, this association is difficult to establish because of the interplay of competing factors. Evidence from Great Britain revealed that average travel distance is lower in larger than in smaller settlements (Stead, 2001), whereas no easily identifiable relationship found in the ten largest urban areas in the United States (Peter Gordon, Kumar, \& Richardson, 1989).

In addition, literature has documented the impact of socioeconomic and cultural variables on the patterns of urban mobility (Chapman, 2007; Schwanen, Dieleman, \& Dijst, 2001; Stead \& Marshall, 2001). Some of the socio-economic and cultural variables have explanatory power greater than the urban form-related variables (Schimek, 1996; Stead, 2001). A few studies focusing on developing economies demonstrated strong positive correlation between energy demand (or transport) and urbanization, including other developmental factors, such as GDP (Sohail Ahmad, Baiocchi, \& Creutzig, 2015; Ibrahim \& Hurst, 1990; Jones, 1991; Krey et al., 2012).

Recently, there is a growing literature on the confounding effect of residential self-selection (RSS) on the influences of built environment characteristics on travel behaviour (Cao, 2014). The debate on RSS in travel fields seeks to answer whether and to what extent spatial differences in travelling may be explained by non-spatial terms, such as explained by the unequal spatial distribution of people's social and personal characteristics, particularly their neighbourhood and travel preferences (Scheiner, 2014). Given constraints of choices in housing and neighbourhood in urban India, the effect of RSS will be low. Moreover, Naess (2014) argued that causal mechanisms by which residential location influences travel behaviour exists, regardless of whether or not transport-related RSS occurs.

\section{Methods and data}

This study attempts multivariate regressions to estimate 'the amount of transport (private and public)', but recognizes correlation between public and private transport. Thus, Seemingly Unrelated Regression Equation (SURE) method is opted (eq.1), which provides efficient estimates than Ordinary Least Squares (OLS), when the error terms in different equations are correlated (Karathodorou et al., 2010). Specific factors that are not accounted for in the model, such as lifestyle and perception, could give rise to 
correlation.

$y_{i j}=x_{i j}^{\prime} \beta_{j}+u_{i j} \ldots$ eq. 1

with $j=1, \ldots, m$ and $i=1, \ldots, N$ representing transport expenditures (private and public) and households respectively. Here $y_{i j}$ is a measure of transport expenditure, $x_{i j}^{\prime}$ denotes the control variables derived from the survey that corresponds determinants of urban mobility and $u_{i j}$ is the error term. After observations stacked, the model of $j$ th equation can be written as eq.2, with the same notations.

$y_{j}=x_{j}^{\prime} \beta_{j}+u_{j} \ldots$ eq. 2

Contrary to the conventional measures of travel behaviour studies, such as, distance or time travelled (Curtis \& Perkins, 2006; Handy, 1996), our study uses out-of-pocket travel expenditure as a proxy for 'the amount of transport'. Private vehicles expenditure includes all expenses of petrol, diesel, lubricants and other fuels for vehicles for last 30 days. Whereas public transport expenditure includes all expenses related to public transport -- railway fare, bus/train fare, taxi fare, steamer or boat fare, rickshaw (hand drawn and cycle) fare, horse cart fare, porter charges and school bus/van fee, and other conveyance expenses for last 30 days. The cost of conveyance is different for public and private transport; thereby estimates are made separately. The out-of-pocket travel expenditure not necessarily reflects actual travel by the public or private means of transport, given differences in fuels prices between cities and different vehicle characteristics. In addition, there is the likelihood that out-of-pocket expenditures are misreported. However, having the lack of other variables such as distance and time, it is appropriate to use out-of-pocket travel expenditure as a proxy variable (Rodríguez \& Joo, 2004; Yihua Liao, 2006). This assumption will not hinder in drawing logical conclusions, particularly related to sustainability aspects (viz. reduced use of gasoline). While interpreting results this limitation should be kept in mind.

This study uses logit regression to model choices between motorized versus non-motorized, and private versus public transport. This is binary outcome model, which estimate the probability that $\mathrm{y}=1$ as a function of the independent variables, and $\mathrm{F}\left(x^{\prime} \beta\right)$ is the cumulative distribution function of the logistic distribution, where $x^{\prime}$ represents total number of explanatory variables (eq. 3 ).

$\mathrm{p}=\operatorname{pr}[y=1 \mid x]=\mathrm{F}\left(x^{\prime} \beta\right)$, where $\mathrm{F}\left(x^{\prime} \beta\right)=\frac{\exp \left(x^{\prime} \beta\right)}{1+\exp \left(x^{\prime} \beta\right)} \ldots$ eq.3

Models use all types of travelling, including work. Non-motorized users are those households who have no expenditure either on private or on public transport. Whereas motorized transport users are those households with any expenditure on public or private transport. While modelling public versus private transport, we distinguish the users. In the case of modelling public versus private transport, public transport users are those households having only public transport expenditure, and private transport users are those having only private transport expenditure. Thus, a few households (\#35) using both modes of transport in the sample are excluded from the analysis.

All models have the same explanatory variables: three city related variables, seven socio-economic variables, and two socio-cultural variables. City related variables include built density, city size dummy, 
and capital city dummy. City size dummy classifies cities into four classes based on population: less than $1 \mathrm{M}$; 1-5 M; 5-10 M; and more than $10 \mathrm{M}$. City size plays important role in spatial planning interventions, for instance, the Jawaharlal Nehru National Urban Renewal Mission (JnNURM), 2005-14, was a massive city-modernization scheme launched in large cities by the Government of India under Ministry of Urban Development. Therefore, analysis uses city size as dummy variable. Similarly, to capture biased infrastructures investment towards capital cities, capital city dummy is used. The socio-economic characteristics include consumption expenditure, land ownership dummy, housing tenure dummy, household size, employment dummy and occupation dummy. Socio-cultural variables include social and religion groups. The estimate misses variables such as attitudes and perception, but socio-economic and cultural variables cover psychological aspects partly. Although supply side of transport infrastructures (e.g., number of public vehicles) affects mobility to a certain extent, it is not used in the estimates because of unavailability of data. However, transport infrastructure supply and demand (as estimated in this paper) is to some extent a chicken-and-egg problem and the two are co-constitutive (van de Coevering \& Schwanen, 2006).

This study uses the $66^{\text {th }}$ round (July 2009 - June 2010) National Sample Survey's 'Household Consumer Expenditure', which is a stratified multi-stage design, initially consisting of over 41,000 households and 178,457 individuals from urban India (NSSO, 2010b). The built density data come from the Demographia (2012), often urban scholars have used (Chen \& Zhou, 2004; I. Gordon, 2008; Turok, 2011), and is available for cities over size of 170,000 population (about 98 cities), which account for about 12,000 sample households.

Indian cities are generally denser than the Western European and the North American cities (Demographia, 2012), partially driven by informality and inadequate infrastructure for long distance mobility. India's urban density (98 cities with population range from 170,000 to 22.24 million) varies between 4,722 and 34,375 people $/ \mathrm{km}^{2}$, with mean value 13,997 people $/ \mathrm{km}^{2}$ (SD: 5,496 ). Densities of metro cities enormously vary between 30,970 persons per $\mathrm{km}^{2}$ (Mumbai) to 11,448 persons per $\mathrm{km}^{2}$ (Delhi). Density is positively but weakly associated with city-size [density $=0.0003 *$ city size (in million) $\left.+13487 ; \mathrm{R}^{2}=0.023\right]$; thus, large cities are not necessarily denser than small cities. Therefore, contrary to the common beliefs, Indian cities have the potential for densification, provided adequate infrastructures are laid.

\section{Results and discussion}

Table 1 presents the descriptive statistics. In comparison to public transport, the share of private transport is relatively higher in small cities and lower in large cities. Households living in capital cities use more public transport than non-capital cities. Typical profiles of households using public and non-motorized transport are poor socio-economic status, for instance, low-income households, employed as casual labourers and low skilled workers, and belong to socio-culturally disadvantaged communities such as Scheduled Castes (SC)/Scheduled Tribes (ST) and Muslim households.

Table 2 presents estimates of the amount of transport (public and private separately) and modal choices. All models have moderate level of goodness to fit (adjusted $\mathrm{R}^{2}$ over 0.19 ). The models check for multicollinearity problems using Variance Inflation Factor (VIF) and variables are adjusted accordingly. 
For instance, when state GDP per capita and state dummy were used together, models revealed multicollinearity, and therefore were adjusted accordingly by eliminating one of them.

Insert Table 1 here: Descriptive statistics of sample households from selected Indian cities, 2010

Insert Table 2 here: Estimates of transportation expenditure per household and modal choice model from selected Indian cities, 2010

\section{Effects of urban infrastructure, density and size}

Density significantly reduces the public and private out-of-pocket travel expenditure, which are a proxy for the amount of transport, which could be both travel distance and number of trips. A ten percent increase in density is associated with $1 \sim 1.2 \%$ decrease in the amount of transport, holding other variables constant. It means doubling density can save up to $10 \sim 12 \%$ of the amount of transport. Densification in Indian cities has relatively higher impact in comparison to the cities of developed economies. For instance, a ten percent increase in density reduces vehicle miles of travel (VMT) between $0.5-1 \%$ as an isolated factor, and 1-4\% including associated factors, such as regional accessibility and mix in developed economies (Litman \& Steele, 2013). In the case of the United States, a 10\% increase in density leads to merely $0.7 \%$ reduction in household automobile travel (Schimek, 1996). As mentioned earlier, many Indian cities have room for densification, which could significantly reduce the amount of transport. In contrast, households living in denser cities have lower probability to use non-motorized transport, which can be provided through appropriate supply.

The amount of transport increases with city size (by population), after controlling the socio-economic variables. This implies that the amount of transport for all types of activities can be larger in larger cities. This is contradictory to the finding from Great Britain, where the average travel distance is less in larger settlements (Stead, 2001). A household living in a large city (population between 5-10 million) in comparison to a small city (population < 1 million) makes $16.4 \%$ more expenditure on private and $26 \%$ more expenditure on public conveyance, ceteris paribus. The probability to use public and motorized transport increases with city size. Similarly, households living in capital cities, often large-sized cities, prefer public and motorized transport modes, partly because of availability of such infrastructures on account of efficiency. The preference for non-motorized transport could be increased if adequate provision of non-motorized transport infrastructures were made, such as dedicated lanes for pedestrians and bikes.

\section{Effects of income}

The household income (proxy by consumption expenditure) is the single largest determinant of the amount of transport, unsurprisingly, even greater than densification. Similar findings, where the impact of socio-economic variables is greater than the city-related variables, are also reported from the cities of the developed economies (Schimek, 1996; Stead, 2001). On average, a ten percent increase in income augments by $6 \sim 7 \%$ out-of-pocket travel expenditure in public and private transport. It also increases the probability to use private and motorized transport. Expenditure by the lower three quintiles on private transport is lower than public transport; thereafter, higher, ceteris paribus (Fig. 3). Income elasticity of 
transport demand is positive in the highest quintile, while negative elsewhere. This result may imply that households up to the fourth quintile have little room to spend additional income on transportation. In the highest quintile, income elasticity of demand for public and private transport is similar in magnitude; elsewhere, lower for public transport. Another variable, 'own land', a proxy to income, presents the same result: land ownership increases the use of transport (public and private) and probability to use private and motorized transport. Given growing economy of India, adequate public and non-motorized transport infrastructures are urgently required to achieve sustainable and inclusive development.

Insert Fig. 3 here: Transport expenditure and income elasticity of demand by income quintiles, 2009-10

\section{Effects of other variables}

Like developed economies, socio-economically and socio-culturally disadvantaged households travel less, both using private and public transport (Power, 2012). For example, the head of the household with elementary occupation (low skilled) spends $8 \sim 17 \%$ less in comparison to household with professional/managerial and associate-professional occupations, holding other variables constant. Similarly, households with casual labour commute the least, followed by self-employed, after controlling other variables. Indeed, disadvantaged households have strong preference for non-motorized and public transport. Thus, disadvantaged households reveal a certain extent of transport deprivation. These findings are not surprising, given existing inequitable access for urban amenities to certain population groups, such as in Beijing and Karachi (Ahmed, Lu, \& Ye, 2008) and India (S. Ahmad, 2012; Dupont, 2004; Sachar, 2006), and reflect the need for inclusive planning interventions.

\section{Conclusion and policy implications}

This study has investigated patterns of urban mobility in the context of a developing economy aiming to identify factors that influence the amount of urban transport and modal choice. Findings can help to design better transport and urban systems in the cities of developing countries, like India, and avoid many of the unsustainable transportation paths of certain cities in more urbanized and high-income countries. As expected, besides city-related variables, several socio-economic and socio-cultural variables influence urban mobility. Similar to other studies, socio-economic and socio-cultural variables explain the amount of transport and modal choice more than city-related variables, after controlling for other factors. However, causal inferences should be made cautiously, given the indirect measurement of the amount of transport and modal choice in cross-sectional data. Nonetheless, by employing robust empirical analysis this study provides helpful guidance for sustainable and inclusive mobility in Indian cities.

Empirical analyses lend support for the following recommendations to enhance sustainable urban transportation and inclusive development in Indian cities, which may also be applicable to other cities in developing economies. 
Firstly, keeping the existing, and improving and expanding non-motorized and public transport infrastructure can provide an affordable, sustainable, efficient and inclusive mode of transportation in the short and long term, particularly among the disadvantaged. Unlike urban dwellers of developed economies, disadvantaged communities in Indian cities predominantly use non-motorized transport modes. As soon as income increases, these groups tend to increase the use of private and motorized modes. Although non-motorized modes matter in terms of environmental, economic and social benefits (Rahul \& Verma, 2013), they have hardly been on the agenda of the local governments. Instead, some cities in India have enacted policies to constrain their use, such as the case of the recent policy in Kolkata to ban the use of bicycles in certain areas of the cities to give more space for motorized modes (PTI, 2014). Nevertheless, policy-makers have often acknowledged the importance of non-motorized transport (Singh, 2013). Indian cities should prioritize and support non-motorized transport-based infrastructures urgently to avoid a drastic shift to motorized modes that would further exacerbate the transportation problems in Indian cities. Moreover, this would benefit those that most need affordable transport modes and reduce inequalities in access to transportation, as vulnerable and disadvantaged communities have higher preference for the use of non-motorized and public transport. Inclusive development is one of the major challenges in Indian cities and despite intentions it has not been incorporated, as Tiwari (2002) has argued. In addition to being climate friendly, walking and cycling could bring tremendous health cobenefits in an increasing obese population with physical inactivity (Woodcock et al., 2009). In this context, these recommendations would also promote social inclusion in Indian cities.

Secondly, stronger support for the sustainable transport agenda in small- and medium-sized cities could bring tremendous co-benefits in the long term. Households living in small cities, compared to large cities, spend less on transport but have high probability to use private transport. Usually public transport infrastructure in small cities is financially inefficient compared to the metropolitan centres (Badami \& Haider, 2007). India possesses a large number of such small cities, about 415 cities/towns between 100,000 and 1 million inhabitants; therefore, it is crucial to develop better public transport infrastructure focusing on these urban centres, such as promotion of low-cost public transport system with appropriate pricing structures. These centres also need improvements in non-motorized urban infrastructure. Moreover, improving urban transportation could make those small to medium size cities more attractive to the growing urban population and mitigate the move to the mushrooming mega-cities.

Thirdly, densification seems to be still a viable option to reduce the amount of transport and promote sustainable modes of transport in Indian urban areas, just as argued for cities in the richer countries (OECD, 2012). Although Indian cities are already highly dense (in terms of average density), there is an opportunity for articulated densification, which could be strategically introduced across parts of the metropolitan areas, as Suzuki et al (2013) suggest (for detailed discussion see Ahmad et al. (2016)). To increase the built density, currently draconian height limits could be eased in India, as Brueckner and Sridhar (2012) have argued, though measures to avoid gentrification should be put in place. A calculated move for articulated densification in Indian cities, with appropriate infrastructures, has potential to address some other pressing issues such as housing shortage.

Finally, a mix of push and pull measures should be in place to move the growing numbers of highincome commuters to more sustainable modes. High-income households account for a large amount of transport, often with private transportation modes (two- and four-wheelers). Switching them to more 
sustainable modes of transport would lead to several co-benefits, including social inclusion, health and environmental improvement. In this context, provision of non-motorized and public transport infrastructures could already be a strategy for transport switching. However, higher income households do not necessarily shift modes with the "right" supply of alternatives, as the income elasticity of the demand shows (see Fig. 3). Nevertheless, given deficits in public and non-motorized transport infrastructures in Indian cities (and other cities of developing countries), we can assume that a significant amount of transport switching could happen (see Shirgaokar, (2014). As incomes rise in the country, there is no other alternative than massive and significant improvements in public and non-motorized infrastructure to avoid intractable transportation problems. For example, vehicle penetration in India is still low -- passenger cars per 1,000 inhabitants is 13 (National Transport Development Policy Committee - India, 2014) -- but cities are already overwhelmed with traffic-related problems, such as pollution and congestion (Pucher et al., 2005; Sudhakara Reddy \& Balachandra, 2012). Moreover, in the coming decades, car ownership could be multiplied by 10 or 20 , which could have enormous socio-economic and environmental implications or even lead to a collapse in urban transport systems. Thus, negative incentives should be considered to reduce the use of private modes, such as a congestion charge for driving in the central areas of the city (e.g., London) and high parking fees and high taxes on cars, whose revenues could also be used to finance public and non-motorized transport infrastructures. These cities still have room to act before following the unsustainable path of some cities in more advanced economies, but policy-makers need to start thinking differently immediately to plan the urban environment and provide transport infrastructure before it is too late. Additionally, provision of monthly-prepaid public transport passes, rather than private transport allowances, as many employers do, would be an effective tool in promoting the use of public transport. For instance, given low level of ridership in the Mass Rapid Transit System in Indian metros, such intervention would be welcomed. Prepaid public transport passes are used in other Asian cities, such as Seoul and Tokyo, and has potential for success in Indian cities, especially in large cities, where public transport infrastructure is more widely available. Nevertheless, the quality of the public transportation (e.g., comfort and reliability) should be improved as well.

In conclusion, public policies in developing countries should urgently focus on enabling strategies for expanding non-motorized and public transport infrastructures in cities, particularly among small and medium-sized cities, to avoid unsustainable patterns of urban transport. Cities in developing countries are growing at a fast pace, which, allied with the rise in average income, leads to a trend of increasing use of individual motorized transport. Thus, if proper transportation infrastructure (alternative to private transport) is not provided, the scale of urbanization can lead to significant increase in congestion, pollution and carbon emissions, with huge economic and social consequences. This study provides some insights on how to move forward the sustainable transportation agenda in developing countries based on empirical evidence from one of those countries, which will be valuable to policy-makers and researchers working in these new urban frontiers. Like other studies of cities in developing countries, we faced data limitations for travel demand modelling at the national or city level. For further analysis, surveys and censuses need to include detailed data collection on trips, land use and socio-economic and socio-cultural variables. Even city-level data would allow us to perform activity-based travel demand modelling rather than trip-based analysis (as we did) against finer variables of land use. Such analysis will allow us to extract finer policy interventions related to land use planning. 


\section{Acknowledgements}

The paper has benefitted from comments received on earlier versions from the participants of seminar presentations at the 2012 Advanced Training Workshop on Urban Spatial Planning in Response to Climate Change in Asia, National Taipei University, New Taipei City (25-30 November) and the Beijing Forum 2013, Beijing (1-3 November). We thank Robert A. Irwin and Elizabeth M. Fox for their professional advice in polishing the language of the manuscript. SA thankfully acknowledges his former institutions -- United National University -- Institute for the Advanced Study of Sustainability (UNU-IAS), Tokyo, the Graduate School of Decision Science and Technology, Tokyo Institute of Technology, Tokyo, the School of Planning and Architecture, Vijayawada, and the Laboratory for Integrated Research and Action for Human Settlements (LabSet), Delhi -- where part of the research was conducted. SA acknowledges partial financial support from the Japan Society for the Promotion of Science (JSPS) and the Alexander von Humboldt Foundation. The authors thank the National Sample Survey Office (NSSO), Ministry of Statistics and Programme Implementation of the Government of India for providing dataset.

\section{References}

Ahmad, S. (2012) 'Housing Inequality in Socially Disadvantaged Communities Evidence from Urban India, 2009', Environment and Urbanization Asia, 3(1), pp. 237-249

Ahmad, S., Avtar, R., Sethi, M., Surjan, A. (2016) 'Delhi's land cover change in post transit era', Cities, 50(pp. 111-118

Ahmad, S., Baiocchi, G., Creutzig, F. (2015) 'CO2 Emissions from Direct Energy Use of Urban Households in India', Environmental Science \& Technology, 49(19), pp. 11312-11320

Ahmed, Q.I., Lu, H., Ye, S. (2008) 'Urban transportation and equity: A case study of Beijing and Karachi', Transportation Research Part A: Policy and Practice, 42(1), pp. 125-139

Badami, M.G., Haider, M. (2007) 'An analysis of public bus transit performance in Indian cities', Transportation Research Part A: Policy and Practice, 41(10), pp. 961-981

Bhagat, R. (2004) 'Dynamics of urban population growth by size class of towns and cities in India', Demography India, 33(1), pp. 47

Bhagat, R. (2011) 'Emerging pattern of urbanisation in India', Economic and political weekly, 46), pp. $10-12$

Brueckner, J.K., Sridhar, K.S. (2012) 'Measuring welfare gains from relaxation of land-use restrictions: The case of India's building-height limits', Regional Science and Urban Economics, 42(6), pp. 1061-1067

Cao, J. (2014) 'Residential self-selection in the relationships between the built environment and travel behavior: Introduction to the special issue', Journal of Transport and Land Use, $7(3)$, pp. 1-3

Census of India (2011a) 'Primary Census Abstract Data Tables (India \& States/UTs Town/Village/Ward Level)', in Office of the Registrar General \& Census Commissioner, I. 
(ed), Delhi.

Census of India (2011b) 'Provisional Population Totals Paper 2 of 2011 India Series 1', Office of the Registrar General \& Census Commissioner, India.

Chapman, L. (2007) 'Transport and climate change: a review', Journal of Transport Geography, 15(5), pp. 354-367

Chen, Y., Zhou, Y. (2004) 'Multi-fractal measures of city-size distributions based on the threeparameter Zipf model', Chaos, Solitons \& Fractals, 22(4), pp. 793-805

Creutzig, F. (2014) 'How fuel prices determine public transport infrastructure, modal shares and urban form', Urban Climate,

Creutzig, F., Jochem, P., Edelenbosch, O.Y., Mattauch, L., Vuuren, D.P.v., McCollum, D., Minx, J. (2015) 'Transport: A roadblock to climate change mitigation?', Science, 350(6263), pp. 911-912

Curtis, C., Perkins, T. (2006) 'Travel Behaviour: A review of recent literature', Curtin University, Perth.

Demographia (2012) 'Demographia World Urban Areas (World Agglomerations)', 8th Annual Edition(Version 2),

Dupont, V. (2004) 'Socio-spatial differentiation and residential segregation in Delhi: a question of scale?', Geoforum, 35(2), pp. 157-175

Ewing, R., Cervero, R. (2010) 'Travel and the built environment', Journal of the American planning association, 76(3), pp. 265-294

Gordon, I. (2008) 'Density and the built environment', Energy Policy, 36(12), pp. 4652-4656

Gordon, P., Kumar, A., Richardson, H.W. (1989) 'Congestion, changing metropolitan structure, and city size in the United States', International Regional Science Review, 12(1), pp. 4556

Gordon, P., Richardson, H.W. (1989) 'Gasoline consumption and cities: A reply', Journal of the American Planning Association, 55(3), pp. 342-346

Handy, S. (1996) 'Methodologies for exploring the link between urban form and travel behavior', Transportation Research Part D: Transport and Environment, 1(2), pp. 151-165

Huang, J., Lu, X., Sellers, J.M. (2007) 'A global comparative analysis of urban form: Applying spatial metrics and remote sensing', Landscape and Urban Planning, 82(4), pp. 184-197

Ibrahim, I.B., Hurst, C. (1990) 'Estimating energy and oil demand functions: A study of thirteen developing countries', Energy Economics, 12(2), pp. 93-102

IEA (2008) World Energy Outlook 2008. OECD/IEA, Paris.

Jabareen, Y.R. (2006) 'Sustainable Urban Forms Their Typologies, Models, and Concepts', Journal of Planning Education and Research, 26(1), pp. 38-52

Jenks, M. (2001) Compact cities: sustainable urban forms for developing countries. Routledge.

Jones, D.W. (1991) 'How urbanization affects energy-use in developing countries', Energy Policy, 19(7), pp. 621-630

Karathodorou, N., Graham, D.J., Noland, R.B. (2010) 'Estimating the effect of urban density on fuel demand', Energy Economics, 32(1), pp. 86-92

Krey, V., O'Neill, B.C., van Ruijven, B., Chaturvedi, V., Daioglou, V., Eom, J., Jiang, L., Nagai, Y., Pachauri, S., Ren, X. (2012) 'Urban and rural energy use and carbon dioxide emissions in Asia', Energy Economics, 34, Supplement 3(0), pp. S272-S283

Litman, T., Steele, R. (2013) 'Land use impacts on transport: How land use factors affect travel 
behaviour', Victoria Transport Policy Institute (www. vtpi. org), pp. 80

Lohrey, S., Creutzig, F. (2015) 'A 'sustainability window' of urban form', Transportation Research Part D: Transport and Environment,

Makido, Y., Dhakal, S., Yamagata, Y. (2012) 'Relationship between urban form and CO2 emissions: Evidence from fifty Japanese cities', Urban Climate, 2(pp. 55-67

Mindali, O., Raveh, A., Salomon, I. (2004) 'Urban density and energy consumption: a new look at old statistics', Transportation Research Part A: Policy and Practice, 38(2), pp. 143-162

Ministry of Urban Development (2011) 'Report on Indian Urban Infrastructure and Services', Delhi.

Moore, A.T., Staley, S.R., Poole, R.W. (2010) 'The role of VMT reduction in meeting climate change policy goals', Transportation Research Part A: Policy and Practice, 44(8), pp. 565574

MOUD (2008) 'Study on Traffic and Transportation Policies and Strategies in Urban Areas in India', pp. 114

Naess, P. (1995) 'Travelling distances, modal split and transportation energy in thirty residential areas in Oslo', Journal of Environmental Planning and Management, 38(3), pp. 349-370

Naess, P. (2014) 'Tempest in a teapot: The exaggerated problem of transport-related residential self-selection as a source of error in empirical studies', Journal of Transport and Land Use, 7(3), pp. 57-79

National Transport Development Policy Committee - India (2014) 'India Transport Report: Moving India to 2032', Routledge India, New Delhi.

Newman, P.W.G., Kenworthy, J.R. (1989) 'Gasoline consumption and cities', Journal of the American Planning Association, 55(1), pp. 24-37

NSSO (2010b) 'Household Consumer Expenditure', National Sample Survey Organization, Ministry of Statistics and Programme Implementation, Government of India, Delhi.

OECD (2012) Compact City Policies: A Comparative Assessment OECD Publishing.

Power, A. (2012) 'Social inequality, disadvantaged neighbourhoods and transport deprivation: an assessment of the historical influence of housing policies', Journal of Transport Geography, 21(0), pp. 39-48

PTI (2014) 'Fresh notification on banning cycles in Kolkata', The Hindu.

Pucher, J., Korattyswaropam, N., Mittal, N., Ittyerah, N. (2005) 'Urban transport crisis in India', Transport Policy, 12(3), pp. 185-198

Puppim de Oliveira, J.A., Jing, Y., Collins, P. (2015) 'Public Administration for Development: Trends and the Way Forward', Public Administration and Development, 35(2), pp. 65-72

Rabinovitch, J., Leitmann, J. (1993) 'Environmental innovation and management in Curitiba, Brazil', UMP Working Paper Series 1, UNDP/UNCHS (Habitat)/World Bank, Washington, D.C.

Rahul, T.M., Verma, A. (2013) 'Economic impact of non-motorized transportation in Indian cities', Research in Transportation Economics, 38(1), pp. 22-34

Rodríguez, D.A., Joo, J. (2004) 'The relationship between non-motorized mode choice and the local physical environment', Transportation Research Part D: Transport and Environment, 9(2), pp. 151-173

Sachar, R. (2006) 'Sachar Committee Report on Social, Economic and Educational Status of the Muslim Community in India', New Delhi: Government of India. 
Scheiner, J. (2014) 'Residential self-selection in travel behavior: Towards an integration into mobility biographies', Journal of Transport and Land Use, 7(3), pp. 15-28

Schimek, P. (1996) 'Household Motor Vehicle Ownership and Use: How Much Does Residential Density Matter?', Transportation Research Record: Journal of the Transportation Research Board, 1552(-1), pp. 120-125

Schneider, A., Woodcock, C.E. (2008) 'Compact, dispersed, fragmented, extensive? A comparison of urban growth in twenty-five global cities using remotely sensed data, pattern metrics and census information', Urban studies, 45(3), pp. 659-692

Schwanen, T., Dieleman, F.M., Dijst, M. (2001) 'Travel behaviour in Dutch monocentric and policentric urban systems', Journal of Transport Geography, 9(3), pp. 173-186

Sethi, M., Puppim de Oliveira, J. (2015) 'From global 'North-South' to local 'Urban-Rural': A shifting paradigm in climate governance?', Urban Climate, 14, Part 4(pp. 529-543

Sethi, M., Puppim de Oliveira, J. (2016, forthcoming) Cities and Climate Co-Benefits: Urban Innovations and Reforms in India. Sage Press, New Delhi.

Shirgaokar, M. (2014) 'Employment centers and travel behavior: exploring the work commute of Mumbai's rapidly motorizing middle class', Journal of Transport Geography, 41(pp. 249258

Sims, R., R. Schaeffer, F. Creutzig, X. Cruz-Núñez, M. D’Agosto, D. Dimitriu, M. J. Figueroa Meza, L. Fulton, S. Kobayashi, O. Lah, A. McKinnon, P. Newman, M. Ouyang, J. J. Schauer, D. Sperling, Tiwari, G. (2014) 'Transport', in Edenhofer, O., R. Pichs-Madruga, Y. Sokona, E. Farahani, S. Kadner, K. Seyboth, A. Adler, I. Baum, S. Brunner, P. Eickemeier, B. Kriemann, J. Savolainen, S. Schlömer, C. von Stechow, T. Zwickel, Minx, J.C. (eds) Climate Change 2014: Mitigation of Climate Change. Contribution of Working Group III to the Fifth Assessment Report of the Intergovernmental Panel on Climate Change, Cambridge University Press, Cambridge, United Kingdom and New York, NY, USA.

Singh, T.L. (2013) 'Non-motorised transport policy on cards', The Hindu, Hyderabad.

Stead, D. (2001) 'Relationships between land use, socioeconomic factors, and travel patterns in Britain', Environment and planning B, 28(4), pp. 499-528

Stead, D., Marshall, S. (2001) 'The relationships between urban form and travel patterns. An international review and evaluation', European Journal of Transport and Infrastructure Research, 1(2), pp. 113-141

Su, Q. (2011) 'The effect of population density, road network density, and congestion on household gasoline consumption in US urban areas', Energy Economics, 33(3), pp. 445452

Sudhakara Reddy, B., Balachandra, P. (2012) 'Urban mobility: A comparative analysis of megacities of India', Transport Policy, 21(0), pp. 152-164

Suzuki, H., Cervero, R., luchi, K. (2013) Transforming cities with transit: Transit and land-use integration for sustainable urban development. World Bank Publications.

Tiwari, G. (2002) 'Urban transport priorities: meeting the challenge of socio-economic diversity in cities, a case study of Delhi, India', Cities, 19(2), pp. 95-103

Turok, I. (2011) 'Deconstructing density: strategic dilemmas confronting the post-apartheid city', Cities, 28(5), pp. 470-477

UN - United Nations (2015) Resolution A/RES/70/1 adopted by the General Assembly at its Seventieth session on 25 September 2015. Transforming our world: the 2030 Agenda for 
Sustainable Development. Available from https://sustainabledevelopment.un.org/ post2015/transformingourworld.

UNDESA - United Nations Department of Economic and Social Affairs (2014) 'World Urbanization Prospects: The 2014 Revision, , CD-ROM Edition.'.

Vaidya, C., Ray, S. (2011) 'Planning for sustainable urban forms for Indian cities', Urban India, 31(2), pp. 32-49

van de Coevering, P., Schwanen, T. (2006) 'Re-evaluating the impact of urban form on travel patternsin Europe and North-America', Transport Policy, 13(3), pp. 229-239

Woodcock, J., Edwards, P., Tonne, C., Armstrong, B.G., Ashiru, O., Banister, D., Beevers, S., Chalabi, Z., Chowdhury, Z., Cohen, A. (2009) 'Public health benefits of strategies to reduce greenhouse-gas emissions: urban land transport', The Lancet, 374(9705), pp. 1930-1943

Yihua Liao, P. (2006) 'Transportation expenditures and ability to pay: evidence from consumer expenditure survey', Transportation Research Record: Journal of the Transportation Research Board, 1985), pp. 257-265 
Fig. 1: Number of cities and percentage of urban population by urban settlement size in India, $1990-2025$

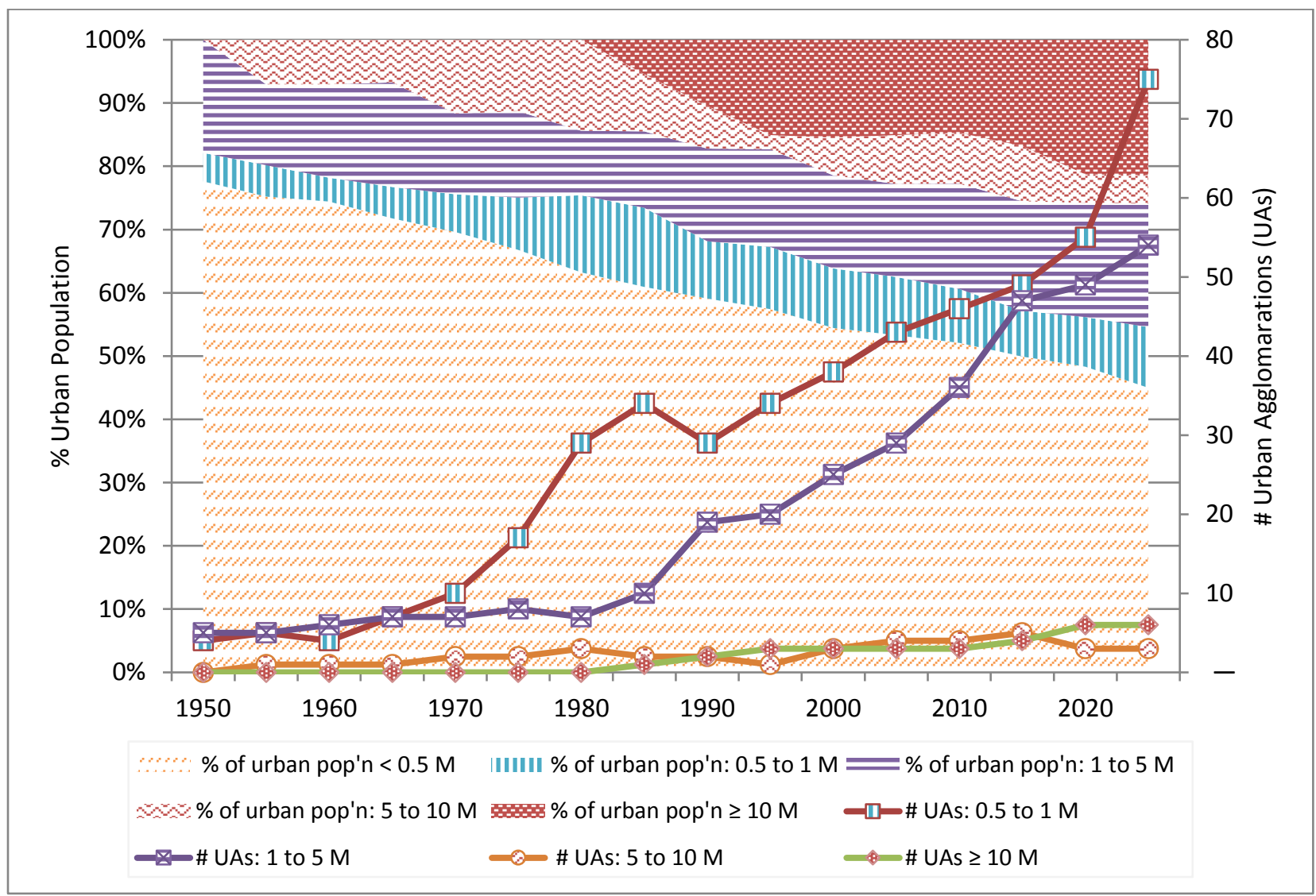

Notes: Data after 2010 are estimated values.

Source: UN-DESA (2014) 
Fig. 2: Mode share (number of trips) by city size, 2007

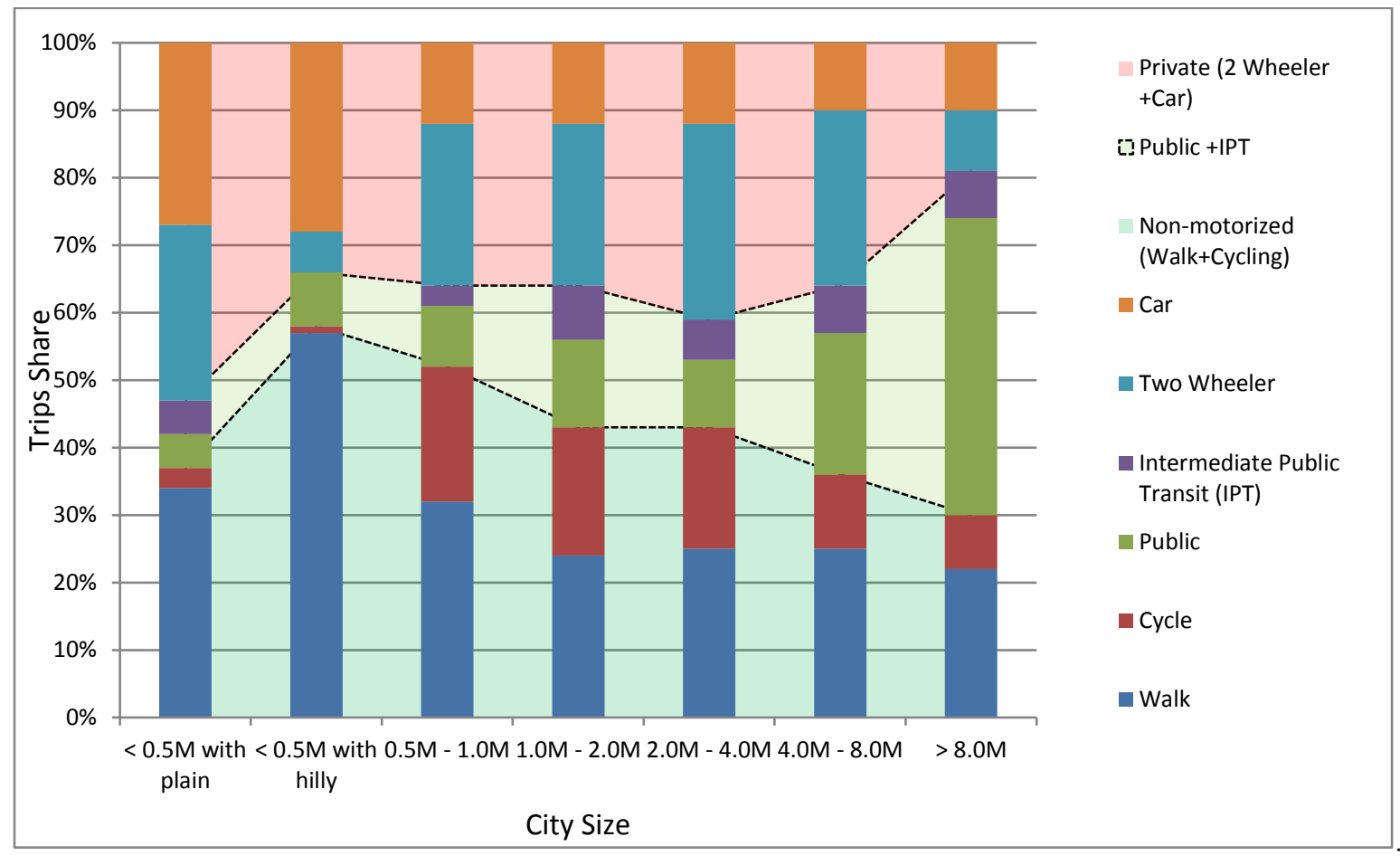

Source: (MOUD, 2008) 
Fig. 3: Transport expenditure and income elasticity of demand by income quintiles, 2009-10

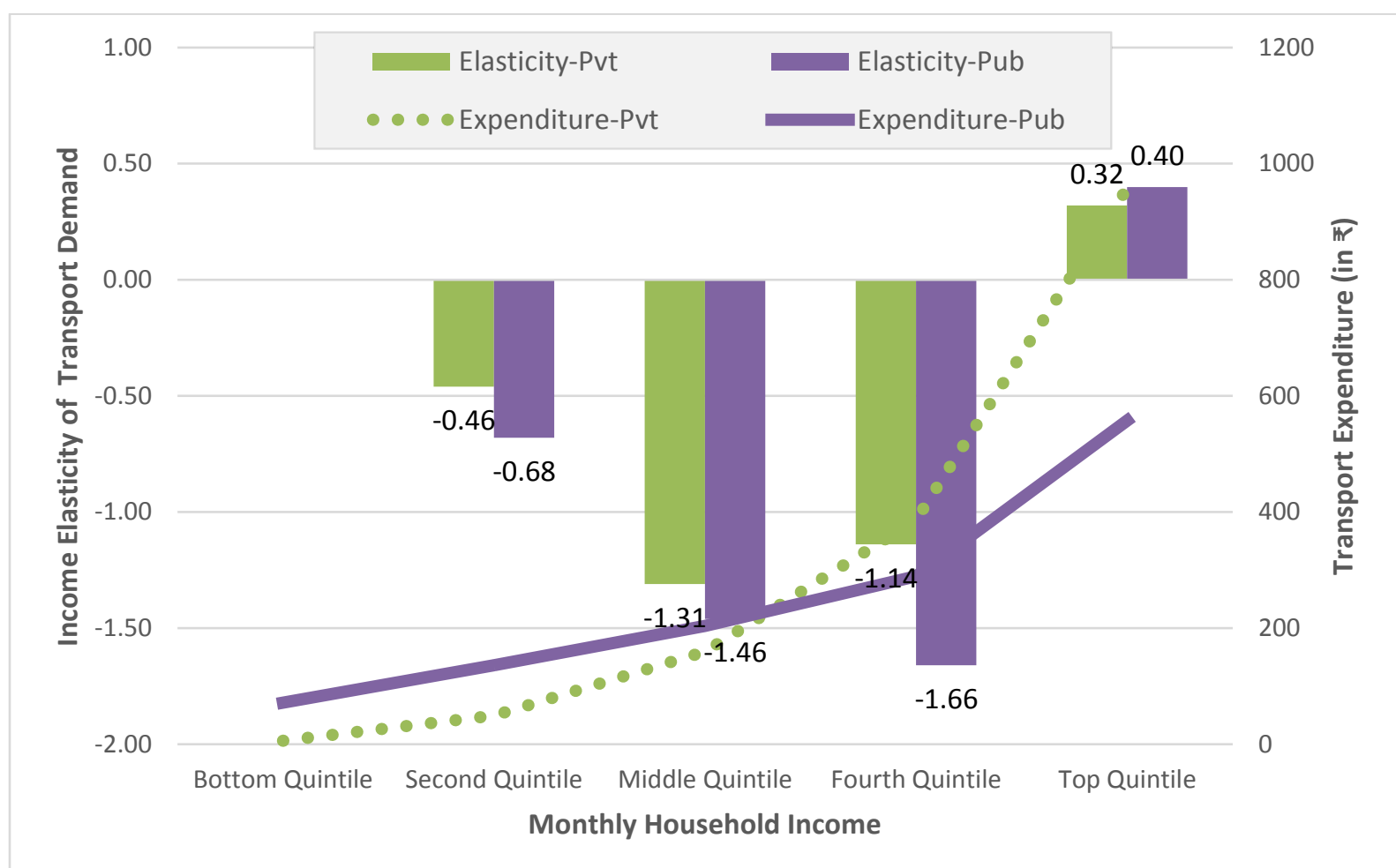

Note: 1. The average monthly income (more precisely consumption expenditure) per household by quintiles vary as following (in ₹) Q1-2448; Q2-4405; Q3-6372; Q4-9130; and Q5-18,548. 2. The income elasticity is calculated using the same method, as employed in this study (table 2). 3. Exp-Pvt: expenditure on private transport; Exp-Pub: expenditure on public transport; IE-Pvt: income elasticity of demand for private transport; and IE-Pub: income elasticity of demand for public transport. 
Table 1: Descriptive statistics of sample households from selected Indian cities, 2010

\begin{tabular}{|c|c|c|c|c|c|}
\hline \multirow{2}{*}{\multicolumn{2}{|c|}{ Variables }} & Private $(5,237)$ & Public $(7,629)$ & Motorized $(12,866)$ & $\begin{array}{c}\text { Non-Motorized } \\
(1,464)\end{array}$ \\
\hline & & Mean (SD) & Mean (SD) & Mean (SD) & Mean (SD) \\
\hline \multirow{6}{*}{ 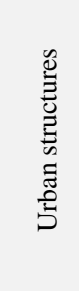 } & Density $^{\gamma}$ (people/km2) & $14217.76(6208.86)$ & $15248.04(7194.65)$ & $14827.02(6827.63)$ & $14517.60(6694.65)$ \\
\hline & City size: <1M (\%) & 0.20 & 0.15 & 0.17 & 0.25 \\
\hline & City size: 1 5M (\%) & 0.38 & 0.30 & 0.33 & 0.37 \\
\hline & City size: 5 10M (\%) & 0.26 & 0.16 & 0.20 & 0.13 \\
\hline & City size: > 10M (\%) & 0.16 & 0.39 & 0.30 & 0.24 \\
\hline & Capital city (yes=1) $(\%)$ & 0.37 & 0.44 & 0.41 & 0.33 \\
\hline \multirow{12}{*}{ 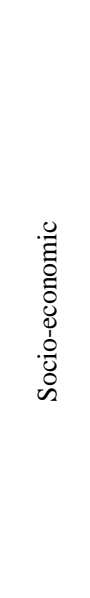 } & Income $^{\gamma}$ (MCE in`000 ₹) & $12.23(15.24)$ & $6.23(7.53)$ & $8.67(11.69)$ & $3.83(2.59)$ \\
\hline & Own land (yes=1) $(\%)$ & 0.80 & 0.65 & 0.71 & 0.56 \\
\hline & Dwelling tenure $($ own $=1)(\%)$ & 0.60 & 0.64 & 0.62 & 0.62 \\
\hline & Household-size ${ }^{\gamma}$ & $4.67(2.24)$ & $4.02(2.27)$ & $4.29(2.28)$ & $3.62(2.37)$ \\
\hline & Regular wage/salary (\%) & 0.48 & 0.43 & 0.45 & 0.37 \\
\hline & Self-employed (\%) & 0.42 & 0.30 & 0.35 & 0.29 \\
\hline & Casual labour (\%) & 0.03 & 0.15 & 0.10 & 0.20 \\
\hline & Others $(\%)$ & 0.07 & 0.12 & 0.10 & 0.14 \\
\hline & Professional/Managerial (\%) & 0.42 & 0.15 & 0.26 & 0.07 \\
\hline & Associate Professional (\%) & 0.10 & 0.05 & 0.07 & 0.03 \\
\hline & Clerical (\%) & 0.08 & 0.06 & 0.07 & 0.02 \\
\hline & Sales/Service Workers (\%) & 0.29 & 0.46 & 0.39 & 0.46 \\
\hline \multirow{8}{*}{ 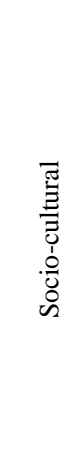 } & Elementary worker (\%) & 0.10 & 0.29 & 0.21 & 0.42 \\
\hline & Social group: SC/ST (\%) & 0.09 & 0.17 & 0.14 & 0.22 \\
\hline & Social group: OBCs (\%) & 0.31 & 0.33 & 0.33 & 0.39 \\
\hline & Social group: General (\%) & 0.60 & 0.50 & 0.54 & 0.39 \\
\hline & Religion-Hindu (\%) & 0.79 & 0.76 & 0.77 & 0.79 \\
\hline & Religion-Islam (\%) & 0.11 & 0.18 & 0.15 & 0.17 \\
\hline & Religion-Christian (\%) & 0.03 & 0.02 & 0.02 & 0.02 \\
\hline & $\begin{array}{l}\text { Religion-Others }(\%) \\
\text { Transport Expenditure } \\
\text { (₹/month/household) }\end{array}$ & $\begin{array}{r}0.07 \\
311.72(659.64)\end{array}$ & $\begin{array}{r}0.04 \\
274.67(444.53)\end{array}$ & $\begin{array}{r}0.05 \\
\text { pvt=347.20 }(687.27) \\
\text { pub=279.60 }(515.22) \\
\end{array}$ & $\begin{array}{r}0.03 \\
0.00(0.00)\end{array}$ \\
\hline
\end{tabular}

Notes: 1. ${ }^{\gamma}$ Table presents SD (in parentheses) for continuous variables, and frequency (in \%) for categorical variables. Religion-Others includes Sikhism, Jainism, Buddhism, Zoroastrianism and others. MCE: Monthly Consumption Expenditure; pvt: private; pub: public Source: (Demographia, 2012; NSSO, 2010b) 
Table 2: Estimates of transportation expenditure per household and modal choice model from selected Indian cities, 2010

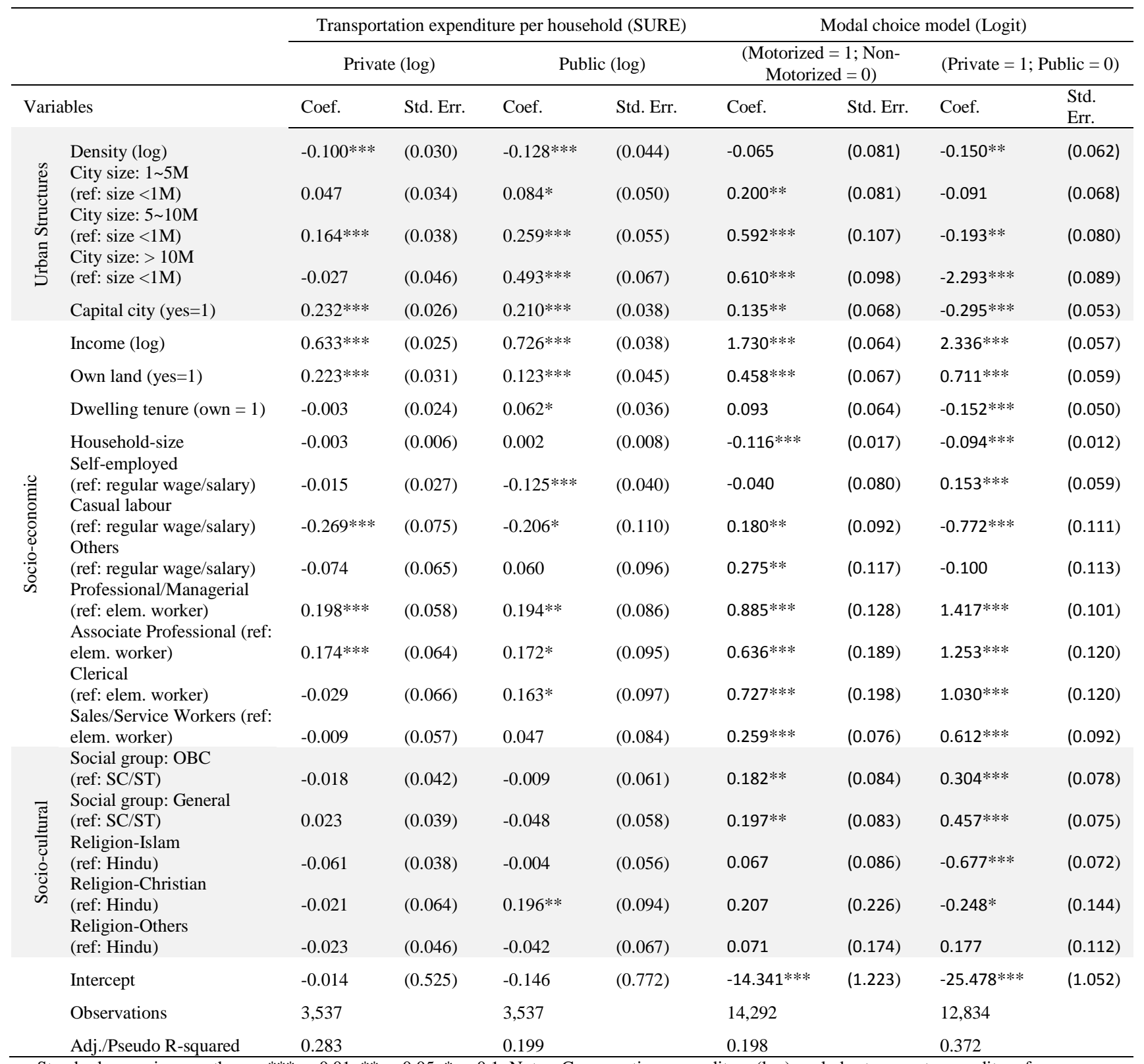

Standard errors in parentheses; $* * * \mathrm{p}<0.01, * * \mathrm{p}<0.05,{ }^{*} \mathrm{p}<0.1 ;$ Notes: Consumption expenditure $(\log )$ excludes transport expenditure for estimate of conveyance expenditure only. Data source: (NSSO, 2010b) 